\title{
Tuz stresi koşullarında yetiştirilen soğanda çay atığı kompostu uygulamalarının etkileri*
}

\section{Ercan EKBİÇ ${ }^{1}$, Ayşe KESKİN ${ }^{1}$}

${ }^{1}$ Ordu Üniversitesi, Ziraat Fakültesi, Bahçe Bitkileri Bölümü, ORDU

*Bu çalışma Ordu Üniversitesi BAP Koordinatörlüğü tarafından desteklenmiştir (Proje No TF-1418).

Alınış tarihi: 01 Mayıs 2018, Kabul tarihi: 16 Mayıs 2018

Sorumlu yazar: Ercan EKBíç, e-posta:ercanekbic@gmail.com

\section{Öz}

$\mathrm{Bu}$ çalışma, tuzlu koşullarda çay atığı kompostu uygulamalarının yeşil soğanda bitki gelişim parametreleri üzerine etkilerini araştırmak amacıyla yürütülmüştür. Deneme, Kantartopu soğan çeşidinin arpacıkları kullanılarak tesadüf parselleri deneme desenine göre 3 tekrarlı olarak kurulmuştur. Çay atığı kompostunun 0, 40, 80 ve 120 g dozları 3 kg'lık saksılara kumlu-tın bünyeli toprak ile karıştırılarak doldurulmuştur. Dikilen arpacıklar 4-5 cm yaprak uzunluğuna geldiğinde bitkiler tuz ( $0 \mathrm{mM}$ ve $75 \mathrm{mM}$ ) stresine maruz birakılmıștır. Bitkiler tuz uygulamasından 30 gün sonra hasat edilmiştir. Hasat edilen bitkilerde bitki gelişim parametreleri ile Na ve K elementi içerikleri incelenmiştir. Tuzlu koşullarda çay atığı kompostu uygulamaları kontrol parsellerine göre bitki taze ve kuru ağırlıkları, aks uzunluğu, yaprak uzunluğu ve kök uzunluğu ile birlikte bitkilerin $\mathrm{K}$ içeriği değerlerini önemli derecede artırmıştır. Çay atığı kompostunun artan seviyesi ile birlikte bu parametrelerde artışlar gözlemlenmiştir. Bununla birlikte çay atığı kompostu tuzlu koşullara toleransın bir göstergesi olan $\mathrm{K} / \mathrm{Na}$ oranını da önemli derecede artırmıştır. Çay atığı uygulanmayan tuzlu koşullarda $\mathrm{K} / \mathrm{Na}$ oranı 0.91 iken $120 \mathrm{~g}$ uygulanmış parsellerde bu oran 1.79 olarak belirlenmiştir. Öte yandan tuzlu koşullarda bitki kuru ağırlığı üzerinden hesaplanan tolerans oranlarına bakıldığında artan çay atığı kompostu seviyesi ile birlikte tolerans oranı değerlerinin arttığ görülmüştür. Kontrol koşullarında 0.72 olan tolerans oranı 120 g çay atığı seviyesinde 0.98 olarak belirlenmiștir.
Anahtar kelimeler: Yeşil soğan, tuz stresi, çay atığl, $\mathrm{K} / \mathrm{Na}$, tolerans

Effects of tea waste compost applications on onion grown in salt stress conditions

\section{Abstract}

This study was carried out in the implementation areas ve laboratories of Ordu University Faculty of Agriculture, Department of Horticulture to determine the effects of tea waste compost applications on the plant growing parameters in saline conditions. The experiment was established by completely randomized plot design with 3 replicates. Sets of Kantartopu onion variety were used as plant material. The levels of $0,40,80$ ve 120 $\mathrm{g}$ of tea waste compost were mixed with $3 \mathrm{~kg}$ of sandy-loam soil ve filled into pots. When onion leaves reached to $4-5 \mathrm{~cm}$ leaf length, plants were stressed with salt $(0 \mathrm{mM}$ ve $75 \mathrm{mM})$. Plants were harvested 30 days after salt application. Plant growth parameters and contents of $\mathrm{Na}$ ve K elements were determined in the harvested plants. Tea waste compost applications increased the fresh and dry biomass, axyl length, leaf length, root length and

$\mathrm{K}$ content comparing to the control plots. Parallel increases were observed with increasing levels of tea waste compost level in the mentioned parameters. In addition the ratio of $\mathrm{K} / \mathrm{Na}$ has also increased significantly. While the ratio of $\mathrm{K} / \mathrm{Na}$ was 0.91 in the plots not applied with tea waste compost it was determined as 1.79 in $120 \mathrm{~g}$ applied plots. On the 
other hand the tolerance ratio values were also increased with increasing tea waste compost levels. The tolerance rate of 0.72 in control plots was 0.98 at $120 \mathrm{~g}$ of tea waste compost plots.

Key words: Green onion, saline stress, tea waste compost, $\mathrm{K} / \mathrm{Na}$, tolerance

\section{Giriş}

Soğan Allium cinsinin en çok üretilen ve tüketilen türüdür. Yeşil soğan iştah açıcı olması, besin içerikleri ve sağlık etkileri nedeniyle dünya mutfaklarının vazgeçilmezidir. Yıl boyunca tohum, küçük arpacık veya iri sofralık soğanlar kullanılarak üretilmektedir. Soğan organik madde bakımından zengin, gevşek yapılı topraklarda iyi gelişmektedir. Soğan yetiştiriciliğinin yapıldığı toprakların organik madde içeriği en az \% 2.5-3 olması beklenir. Ağır karakterli killi topraklar serin iklim koşullarında fazla miktarda su tuttukları için bu tip topraklarda kompost ilavesi önemlidir. Kompost ilavesi yaz döneminde de yüksek sıcaklıklarda toprakların havalanmasına katkı yapmaktadır. Toprakta sağlanan havalanma etkisi ile kök bölgesinde oksijen yoğunluğu artmaktadır. Bunun yanında toprakta faaliyet gösteren yararlı bakterilere besin sağlayarak da toprak patojen zararlanmalarına karşı dolaylı katkı sunmaktadır (Scheuerell ve Mahaffee, 2004). Bitkisel atıklarının doğrudan veya kompostlaştırıldıktan sonra toprağa uygulanması ile toprağın organik madde içeriği artırılabilmektedir (Pascual ve ark., 1997; Fekri ve ark., 2016; Özer, 2017). Topraktaki organik madde miktarı abiyotik stress koşullarına karşı bitkilerin direncini artırabilmektedir. Toprak tuzluluğu, kurak ve yarı kurak bölgelerde karşılaşılan en önemli bir abiyotik stres faktörüdür (Tanji, 1990; Shannon, 1997; Pitman ve Läuchli 2002; Rengasamy, 2006; Suarez, 2006).

Soğan bitkisi tuzluluk stresine oldukça duyarlı bir türdür. Soğan yetiştirilen alanlarda toprak tuzluluğu $1.4 \mathrm{dS} / \mathrm{m}$ 'nin üzerine çıkması istenmez (Voss ve ark., 1999). Global iklim değişikliği ve yanlış tarımsal üretim teknikleri, aşırı gübreleme ile tarım alanlarında tuzluluk sorunları artarak devam etmektedir. Yapılan araştırmalarda dünya tarım alanlarının \% 40'ından fazlasında toprak tuzluluğu sorununun olduğu bildirilmiştir (Serrano ve Gaxicola, 1994; Martinez-Beltran ve Manzur, 2005). Önemli bir tarım ülkesi olan Türkiye'de ise, tarım arazilerinin 1.5 milyon ha'lı kısmında tuzluluk problemi görülmektedir.
Topraktaki tuz miktarının artışıyla bitki gelişimi olumsuz etkilenmekte ve bitkilerde $\mathrm{Na}$ ve ya $\mathrm{Cl}$ toksisitesi ortaya çlkabilmektedir (Saqib ve ark., 2012). Bununla birlikte aşırı tuzluluk bitkide yaprak alanı miktarını düşürerek fotosentez aktivitesini geriletmekte (Ashraf ve ark., 2012) ve bitkide büyüme ve gelişme hormonları ile enzim aktivitelerini azaltmaktadır (Apel ve Hirt, 2004). Böyle durumlarda verimli ve kaliteli bir üretim yapabilmek için topraktaki tuzluluk probleminin giderilmesi gerekmektedir. Bununla birlikte tuzluluk sorunu olan toprakların bitkisel üretime kazveırılması için uygulanan toprak ıslahı yöntemleri pahalı ve zaman alıcıdır. Tuzlu topraklara kompostlanmış organik madde ilavesi pratik bir çözümdür ve aşırı tuzun bitkilerde meydana getirdiği olumsuz etkiler azaltılabilmektedir (Reddy ve Crohn, 2012; Fekri ve ark., 2016).

Çay (Camellia sinensis L.) Türkiye'de Doğu Karadeniz Bölgesi'nin en önemli tarımsal ürünüdür. Bölgede hasat edilen çayların kuru çay olarak işlenmesi sırasında önemli miktarda bitkisel atı ortaya çıkmaktadır. Çay atığının kompostlaştırıldıktan sonra toprağa karıștırılması ile toprağın organik madde miktarı artmakta, besin maddesi içeriği ve su tutma kapasitesi artmaktadır. Bunların yanında kompost kullanımı toprağın fiziksel yapısının iyileştirilmesi ile iyi bir kök gelişimine de imkân verilmektedir (Özenç ve Çalışkan, 2001; Özenç ve Çayci, 2005). Ayrıca çay atığı kompostu tek başına veya diğer bitkisel kompostlarla birlikte karıştırılarak yetiştirme ortamı olarak kullanılabilmektedir (Çağlar, 2015). Kompostlanan organik materyale gübre ilavesi ile hem bitki kitle ağırlığı hem de kimyasal içerikleri de olumlu yönde etkilenmektedir (Karal ve Uğur, 2014).

Bu çalışmada tuz stresi koşullarında yetiştirilen yeşil soğanın gelişimi üzerine farklı miktarlarda toprağa karıştırılan çay atığı kompostunun etkileri araştırılmıştır.

\section{Materyal ve Metot}

$\mathrm{Bu}$ çalışmada, Kantartopu soğan çeşidinin kıskaları bitkisel materyal olarak kullanılmıştır. Kontrol (0 g), $40 \mathrm{~g}, 80 \mathrm{~g}$ ve $120 \mathrm{~g}$ miktarlarındaki çay atığ kompostu 3 kg kumlu-tın bünyeye sahip toprak ile karıştırılarak saksılara doldurulmuştur. Her saksıya temel gübre olarak $300 \mathrm{ppm} \mathrm{N}, 100 \mathrm{ppm}$ P ve 125 ppm K uygulanmış ve kıskalar dikilmiştir. Kıskalar çimlendikten ve yapraklar 4-5 cm uzunluğa eriştikten sonra tuz uygulamasına başlanmıştır. Toplamda $75 \mathrm{mM} \mathrm{NaCl}$ dozu 3 gün ara ile iki kez 
uygulanarak tamamlanmıştır. Deneme tesadüf parselleri deneme desenine göre 3 tekrarlamalı olarak kurulmuştur.

Bitkiler 30 gün süre ile gelişmeye bırakılmış ve gerekli bakım işlemleri uygulanmıștır. Gelișme süresi sonunda bitkiler hasat edilerek temizlenmiștir. Hasat edilen bitkilerde, aks uzunluğu (cm), yaprak uzunluğu (cm), kök uzunluğu (cm), taze ağırlık (g), kuru ağırlık (g), bitkide $\mathrm{Na}$ içeriği (\%), bitkide $\mathrm{K}$ içeriği (\%), $\mathrm{K} / \mathrm{Na}$ ve stres tolerans oranları belirlenmiștir. Bitkinin aks uzunluğu, yaprak uzunluğu ve kök uzunluğu değerleri cetvel ile ölçülerek belirlenmiştir. Bitki yaş ağırlıkları hasat edilen bitkilerin $0.001 \mathrm{~g}$ duyarlı hassas terazide tartılarak, kuru ağırlık ise taze ağırlıkları alınan materyalin $70^{\circ} \mathrm{C}^{\prime}$ lik etüvde 72 saat süre sicaklığa maruz bırakıldıktan sonra $0.001 \mathrm{~g}$ duyarlı hassas terazide tartılarak elde edilmiştir. Bitkide $\mathrm{Na}$ ve $\mathrm{K}$ içeriği değerlerinin belirlenmesi amaciyla kurutulup ögütülen bitkisel materyalden $200 \mathrm{mg}$ hassas terazide tartılarak yüksek ısıya dayanaklı porselen krozelere konulup kül firınında $550^{\circ} \mathrm{C}$ 'de 5 saat süre ile yakılmıştır. Yakılan örneklerin üzerine $2 \mathrm{ml} \mathrm{1/3}$
$\left(\mathrm{HCl} / \mathrm{H}_{2} \mathrm{O}\right)$ oranında hazırlanmış çözelti eklenerek $30 \mathrm{dk}$ beklenip, üzerine $18 \mathrm{ml}$ saf su eklenerek mavi bant filtre kâğıdından geçirilerek stok süzükler elde edilmiştir. Örneklerin $\mathrm{Na}$ ve $\mathrm{K}$ element miktar okumaları Atomik Absorpsiyon cihazında Chapman ve ark. (1961)'na göre yapılmıştır. Stres tolerans oranının belirlenmesinde ise bitki kuru ağırlık değerleri kullanılmıştır. $\mathrm{Bu}$ değerler çay atığı kompostu uygulanmış bitkilerin kuru ağırlık değerlerinin kontrol bitkilerinin kuru ağırlık değerlerine bölünmesiyle hesaplanmıştır.

Denemeden elde edilen veriler JMP v.10.0 istatistik paket programında değerlendirilmiş, ortalamaların karşılaştırılmasında \% 5 önem seviyesinde LSD (Least significance differences) metodu kullanılmıştır.

\section{Bulgular}

Normal ve tuz stresi koşullarında farklı çay atığı kompostu uygulamalarının yeşil soğvea aks uzunluğu, yaprak uzunluğu, kök uzunluğu ile taze ve kuru ağırlık üzerine etkileri Çizelge 1'de verilmiştir.

Çizelge 1. Çay atığı kompostu uygulamalarının bitki gelişimi üzerine etkileri

\begin{tabular}{|c|c|c|c|c|c|c|}
\hline $\mathrm{NaCl}(\mathrm{mM})$ & $\begin{array}{c}\text { Çay Atığ } \\
\text { Kompostu } \\
\text { (g) }\end{array}$ & $\begin{array}{c}\text { Taze ağırlık } \\
\text { (g) }\end{array}$ & $\begin{array}{l}\text { Kuru ağırlık } \\
\text { (g) }\end{array}$ & $\begin{array}{c}\text { Aks } \\
\text { uzunluğu } \\
(\mathrm{cm})\end{array}$ & $\begin{array}{c}\text { Yaprak } \\
\text { uzunluğu } \\
(\mathrm{cm})\end{array}$ & $\begin{array}{c}\text { Kök } \\
\text { uzunluğu } \\
(\mathrm{cm})\end{array}$ \\
\hline \multirow{4}{*}{0} & 0 & $22.24 \mathrm{c}$ & $1.72 \mathrm{c}$ & $3.78 \mathrm{~b}$ & $46.45 \mathrm{~b}$ & $21.34 \mathrm{~b}$ \\
\hline & 40 & $26.82 \mathrm{~b}$ & $1.75 \mathrm{c}$ & $4.47 \mathrm{a}$ & $53.32 \mathrm{a}$ & $24.18 \mathrm{a}$ \\
\hline & 80 & $28.62 \mathrm{~b}$ & $1.92 \mathrm{~b}$ & $4.45 \mathrm{a}$ & $54.77 \mathrm{a}$ & $25.03 \mathrm{a}$ \\
\hline & 120 & $31.35 \mathrm{a}$ & $2.09 \mathrm{a}$ & $4.78 \mathrm{a}$ & $55.87 \mathrm{a}$ & $25.47 \mathrm{a}$ \\
\hline & LSD \%5 & 2.15 & 0.076 & 0.38 & 3.67 & 1.49 \\
\hline \multirow{5}{*}{75} & 0 & $15.57 \mathrm{c}$ & $1.25 \mathrm{~d}$ & $2.80 \mathrm{~b}$ & $30.31 \mathrm{c}$ & $14.02 \mathrm{c}$ \\
\hline & 40 & $16.92 \mathrm{bc}$ & $1.36 \mathrm{c}$ & $3.01 \mathrm{ab}$ & $33.44 \mathrm{~b}$ & $15.90 \mathrm{~b}$ \\
\hline & 80 & $18.90 \mathrm{ab}$ & $1.53 \mathrm{~b}$ & $3.28 \mathrm{ab}$ & $33.83 \mathrm{~b}$ & $16.23 \mathrm{~b}$ \\
\hline & 120 & $19.88 \mathrm{a}$ & $1.69 \mathrm{a}$ & $3.62 \mathrm{a}$ & $36.00 \mathrm{a}$ & $18.48 \mathrm{a}$ \\
\hline & LSD \%5 & 2.04 & 0.06 & 0.80 & 1.46 & 1.02 \\
\hline
\end{tabular}

Tuz stresi ve normal koşullarda yetiştirilen soğanın bitki gelişim parametreleri üzerine etkileri bakımından çay atı̆̆ı kompostunun seviyeleri arasındaki farklılıklar istatistiksel olarak önemli çıkmıştır $(p<0.05)$. Her iki koşuldaki kontrol parselleri dikkate alındığında $75 \mathrm{mM} \quad \mathrm{NaCl}$ uygulamasının bitki taze ağırlığını 22.24 g'dan 15.57 g'a gerileterek \% 42.8'lik bir azalmaya neden olduğu görülmüştür. Çay atığı kompostu uygulanmayan parsellerdeki bitki taze ağırlık değeri 22.24 g'dan 120 g kompost uygulanan parsellerde \% 40.1 artış ile $31.35 \mathrm{~g}$ olmuştur. Benzer bulgular tuz stresi koşullarında da elde edilmiștir. Tuz stresi altındaki bitkilerin kompost uygulanmayan parsellerindeki taze ağırlık değeri $15.57 \mathrm{~g}$ iken $120 \mathrm{~g}$ kompost uygulanan parsellerde \% 27.7'lik artış ile bu değer 19.88 olarak belirlenmiştir. Öte yandan tuz stresi 1.72 g olan kuru ağırlık değerini de 1.25 g'a gerileterek \% 37.6'lik ciddi oranda bir azalmaya neden olmuştur. Çay atığı kompostu uygulamaları bitki kuru ağırlık değerlerinde de etkili bulunmuştur. Normal koşullarda $120 \mathrm{~g}$ çay atığı uygulaması (2.09 g) kontrol parsellerine (1.72 g) göre kuru ağırlık değerini \% 21.5 oranında artırırken tuz stresi koşullarındaki bitkilerde ise kontrol parsellerinde 1.25 g olarak belirlenen değeri 1.69 g'a yükselterek 
\% 35.2 oranında bir artışa neden olmuştur. Kök uzunluğu parametresi incelendiğinde, çay atığı kompostu seviyelerinin etkinliği tuz stresi koşullarında normal koşullara göre daha belirgin çıkmıştır. Normal koşullarda kontrol parsellerindeki bitkilerin kök uzunlukları $21.34 \mathrm{~cm}$ iken artan kompost seviyesi ile birlikte $120 \mathrm{~g}$ kompost uygulanan parsellerde $25.47 \mathrm{~cm}$ olmuştur. Kompostun en yüksek seviyesi kontrole göre \% 19.4 oranında kök uzunluğu artışı meydana getirmiştir. Tuz stresi koşullarındaki kontrolde ise $14.02 \mathrm{~cm}$ olarak ölçülen kök uzunluğu değeri 120 g kompost uygulamasında 18.48 cm'ye yükselmiș ve böylece kontrole göre \% 31.8 oranında bir artış elde edilmiştir.

Çay atığı kompostu uygulamaları normal koşullarda yetiştirilen soğanın aks uzunluğu ve yaprak uzunluğu değerleri üzerine kontrole göre etkili olmuş, ancak kompost seviyeleri arasındaki farklılıklar istatistiksel olarak önemli çıkmamıştır. Normal koşullarda yetiştirilen soğanların kontrol parsellerindeki aks uzunluğu $3.78 \mathrm{~cm}$ ve yaprak uzunluğu $46.45 \mathrm{~cm}$ olarak ölçülürken, $120 \mathrm{~g}$ kompost uygulamasında bu değerler sirasıyla $4.78 \mathrm{~cm}$ ve $55.87 \mathrm{~cm}$ olarak belirlenmiştir. Böylece kompost uygulaması normal koşullarda yetiştirilen bitkilerin aks ve yaprak uzunluğu değerlerinde kontrole göre sırasıyla \% 26.5 ve \% 20.3 oranında artış meydana getirmiştir. Tuz stresi koşullarında ise kontrol parsellerinde aks ve yaprak uzunluğu değerleri sırasıyla $2.80 \mathrm{~cm}$ ve $30.31 \mathrm{~cm}$ olarak ölçülürken 120 g kompost uygulanan parsellerde bu değerler 3.62 cm ve $36.00 \mathrm{~cm}$ olmuştur. Kontrol parsellerine göre yine en yüksek kompost seviyesi uygulanan parsellerde aks ve yaprak uzunluğu bakımından sırasıyla \% 29.3 ve \% 18.8 oranında artışlar elde edilmiştir.

Çay atığı kompostu uygulamalarının bitkide $\mathrm{Na}, \mathrm{K}$ ve $\mathrm{K} / \mathrm{Na}$ oranı üzerine etkilerine ait bulgular Çizelge 2'de verilmiştir. Hem normal hem de tuz stresi koşullarında kontrol parsellerine göre kompost uygulamalarının meydana getirdiği farklılıklar istatistiksel olarak önemli çıkmıştır $(\mathrm{p}<0.05)$. Normal koşullarda yetiştirilen bitkilerin kontrol parsellerinde Na içeriği \% 0.33 iken 80 g ve 120 g kompost uygulanan parsellerde \% 0.21 olarak tespit edilmiştir. Aynı koşullarda yetiştirilen bitkilerin kontrol parsellerindeki bitkilerin $\mathrm{K}$ içeriği \% 7.82 iken 120 g kompost uygulamasında bu değer \% 11.49 olarak belirlenmiştir. Tuz stresi koşullarında yetiştirilen bitkilerde de kompost uygulamalarının bitkilerde $\mathrm{Na}$ ve $\mathrm{K}$ içeriği üzerine etkileri önemli çıkmıştır. Tuz stresi altındaki bitkilere farklı dozlarda uygulanan çay atığı kompostu bitkideki Na içeriğini azaltırken $\mathrm{K}$ içeriğini artırmıştır. Stres altındaki bitkilerin kontrol parsellerindeki Na içeriği \% 4.98 iken $120 \mathrm{~g}$ kompost uygulana parsellerde bu değer \% 3.74'e düşmüştür. Bitkilerin $\mathrm{K}$ içerikleri de kontrol parsellerinde \% 4.52 iken 120 g kompost uygulanan parsellerde \% 6.66 olarak tespit edilmiştir. Buna göre kompost uygulamasının bitkinin $\mathrm{K}$ alımını teşvik ettiği söylemek mümkündür.

Çizelge 2. Çay atığı kompostu uygulamalarının bitkide Na ve K içeriği ile K/Na oranı üzerine etkileri

\begin{tabular}{ccccc}
\hline \multirow{2}{*}{$\mathrm{NaCl}(\mathrm{mM})$} & $\begin{array}{c}\text { Çay atı̆ } \mathrm{l} \\
\text { kompostu(g) }\end{array}$ & $\mathrm{Na}(\%)$ & $\mathrm{K}(\%)$ & $\mathrm{K} / \mathrm{Na}$ \\
\hline & 0 & $0.33 \mathrm{a}$ & $7.82 \mathrm{~b}$ & $23.72 \mathrm{~d}$ \\
\multirow{2}{*}{0} & 40 & $0.24 \mathrm{~b}$ & $10.86 \mathrm{a}$ & $45.05 \mathrm{c}$ \\
& 80 & $0.21 \mathrm{c}$ & $10.46 \mathrm{a}$ & $49.09 \mathrm{~b}$ \\
& 120 & $0.21 \mathrm{c}$ & $11.49 \mathrm{a}$ & $55.45 \mathrm{a}$ \\
\hline & LSD $\% 5$ & 0.028 & 1.21 & $0.91 \mathrm{c}$ \\
\hline & 0 & $4.98 \mathrm{a}$ & $4.52 \mathrm{~b}$ & $1.08 \mathrm{c}$ \\
& 40 & $4.48 \mathrm{a}$ & $4.84 \mathrm{~b}$ & $1.47 \mathrm{~b}$ \\
\hline & 120 & $4.48 \mathrm{a}$ & $6.57 \mathrm{a}$ & $0.23 \mathrm{a}$ \\
\hline
\end{tabular}


Tuz stresi koşullarında bitkinin $\mathrm{Na}$ yerine $\mathrm{K}$ iyonlarını alması bitkiyi Na'nın olumsuz etkilerinden korumaktadır (Dasgan ve ark., 2002). Hem tuz stresi hem de normal koşullarda yetiștirilen soğanlara farklı düzeylerde çay atığı kompostunun uygulanması bitkilerin $\mathrm{K} / \mathrm{Na}$ oranlarına etkili olmuştur. Normal koşullarda yetiştirilen bitkilerin kontrol parsellerinde K/Na oranı 23.72 iken 120 g kompost uygulaması ile bu değer 55.45'e yükselmiştir. Tuz stresi koşullarında ise kontrol parsellerinde yetiştirilen bitkilerin $\mathrm{K} / \mathrm{Na}$ oranı 0.91 iken 120 g kompost uygulaması ile bu oran 1.79'a yükselmiștir. Yürüttüğümüz bu çalıșmada tuz stresi koşullarında çay atığı kompostu uygulaması soğveaki $\mathrm{Na}$ yerine $\mathrm{K}$ alımını teşvik ederek $\mathrm{K} / \mathrm{Na}$ oranını önemli derecede yükseltmiștir.
Tuz stresi koşullarında yetiştirilen bitkilerin kuru ağırlık değerleri kullanılarak hesaplanan tolerans oranlarına ait bulgular Çizelge 3'te verilmiştir. Çizelgede de açıkça görüldüğü gibi kompost seviyesinin artmasıyla bitkilerdeki tolerans oranlarının da arttığı açıkça görülmektedir. Tuz stresi koşullarında kontrol parsellerindeki bitkilerin tolerans oranı 0.72 iken $40 \mathrm{~g}$ kompost uygulamasinda 0.79 'a, 80 g uygulamasinda 0.89 'a ve 120 g kompost uygulamasında da 0.98 'e çlkmıştır. Çay atığı kompostu uygulaması tuz stresi altında yetiştirilen soğanlarda Na'un olumsuz etkilerine karşı bitkilerin tolerans oranlarını artırdığı belirlenmiştir.

Çizelge 3. Çay atığı kompostu uygulamalarının bitkide stres tolerans oranı üzerine etkileri

\begin{tabular}{cc}
\hline Çay Atı̆̆ Kompostu (g) & Tolerans Oranı \\
\hline Control & $0.72 \mathrm{~d}$ \\
40 & $0.79 \mathrm{c}$ \\
80 & $0.89 \mathrm{~b}$ \\
120 & $0.98 \mathrm{a}$ \\
\hline LSD \%5 & 0.03 \\
\hline
\end{tabular}

\section{Sonuç ve Tartışma}

Yapılan çalışmalar incelendiğinde gerek soğanda gerek diğer bitki türlerinde tuz stresinin bitkileri önemli derecede olumsuz etkilediği ve bu olumsuzlukların giderilmesi adına farklı uygulamaların yapıldığı görülmektedir. Hussein ve ark., (2014), soğan yetiştiriciliğinde 3000 ve 6000 ppm dozlarda tuzlu sular ile sulama yapıldığında taze biyomas ağırlıklarında kontrole göre sırasıyla \% 29.1 ve \% 31.9 bir azalmanın olduğunu bildirmişlerdir. Araștırmacılar kuru ağırlık değerlerinde de yine kontrole göre sırasıyla \% 19.2 ve \% 31.9 oranlarında azalmaların olduğunu rapor etmişlerdir. Suhail ve Mahdi (2013), mikoriza uygulamalarının tuz stresi altında yetiștirilen soğanda bitki taze ve kuru ağırlıklarında kontrole göre artışların olduğunu rapor etmişlerdir. Manan ve ark., (2016) domateste yapraktan methyl jasmonate uygulamalarının tuz stresi koşullarındaki bitkilerde fizyolojik ve biyokimyasal dayanıklılığın sağladığını bildirmişlerdir. Bacilio ve ark., (2016) biberde yaptıkları çalışmada hümik asit ve bitki gelişimini teşvik edici bakteri (PGPB) uygulamalarının $75 \mathrm{mM}$ tuz şiddeti koşullarında yaprak kuru ağırlığı değerleri üzerine olumlu etki yaptığını rapor etmişlerdir. Sikder ve ark., (2016) mısır bitkisinde yüksek düzeyde sulama suyu miktarı ile polietilen malç uygulamalarının bitkide tuz stresinin olumsuz etkilerinden kaynaklanan bitki taze ve kuru ağırlık değerleri kaybının giderilebileceğini bildirmişlerdir.

Yürüttüğümüz çalışma sonuçlarına benzer şekilde tuz stresinin kök uzunluğu değerlerini olumsuz etkilediği ve organik madde uygulamalarının bu olumsuz etkiyi azalttığı rapor edilmiştir. Bacilio ve ark., (2016) hümik asit ve PGPB uygulamalarının yüksek tuz stresi altında diğer bazı bitki gelişim parametrelerinde olumlu etki yaparken kök uzunluğu üzerine negatif bir etki yaptığını belirtmişlerdir. Buğdayda yapılan bir çalışmada (Bilkis ve ark., 2016) ise tuz stresinin bitkilerin kök uzunluğunda kontrole göre \%30.4 oranında bir azalmaya neden olduğu ifade edilmiştir.

Tuz stresi koşulları soğanda bitki uzunluğunu da oldukça azaltmaktadır. Yüksek dozdaki (10 dS/m) tuz stresinin soğanda bitki uzunluğunu kontrole göre \% 33.1 azalttığını bildirmişlerdir (Suhail ve Mahdi, 2013). Araştırmacılar yüksek tuz stresi koşullarında mikoriza uygulamalarının bitki uzunluğunu kontrol koşullarına göre \% 8.4 artırdığını tespit etmişlerdir. Soğanda yapılan bir başka çalışmada da (Hussein ve ark., 2014) nikotinik asit ve triptofan uygulamalarının yüksek tuz stresi koşullarında bitki 
boyu değerlerini kontrole göre sirasıyla \% 32 ve \% 24.5 oranında artırdığı belirlenmiştir.

Sodyum elementi kaynaklı tuz stresi koșullarında hassas bitkilerin bünyelerinde $\mathrm{Na}$ konsantrasyonu yüksek seviyelere ulaşarak toksik etkiler meydana getirmektedir. Nispeten toleranslı olan bitkilerde topraktan $\mathrm{Na}$ yerine $\mathrm{K}$ elementinin alımı teşvik edilmekte ve kısmen de olsa sodyumun toksik etkileri en aza indirilmektedir. Lima ve ark. (2006), tuzlu sular ile sulanan topraklarda yetiştirilen soğan bitkilerinin yapraklarında Na miktarının arttığı ve K miktarının da azaldığını bildirmişlerdir. Bu yüzden tuz stresi bakımından genotiplerin taranmasına yönelik yapılan çalışmalarda da $\mathrm{K} / \mathrm{Na}$ oranının önemli bir kriter olduğu görülmektedir (Raza ve ark., 2017). Artan $\mathrm{NaCl}$ stresi şiddeti bitkilerde $\mathrm{K} / \mathrm{Na}$ oranını düşürmektedir (López-Aguilar ve ark., 2012). Biberde yapılan bir çalışmada (Aktaş ve ark., 2006) topraktan Zn uygulamalarının bitkide $\mathrm{K} / \mathrm{Na}$ oranını artırdığı bildirilmiştir. Ayrıca biberde bitki gelişimini teşvik edici bakteri uygulamalarının da K/Na oranını artırdığı bildirilmiştir (Amor ve Cuadra-Crespo, 2012).

$\mathrm{Bu}$ çalışmada tuzlu koşullarda yetiştirilen soğan bitkisi üzerine çay atığı uygulamasıyla bitkideki $\mathrm{K} / \mathrm{Na}$ oranında artış sağladığını ve bu sayede bitkinin tuz stresine olan toleransının da arttığ belirlenmiştir. Elde edilen tüm bu sonuçlar yukarıda belirtilen çalışma sonuçlarıyla da desteklenmektedir.

Yaptığımız bu çalışma ile çay atığı kompostunun toprak strüktürü ve mikrobiyal yaşamına yapmış olduğu olumlu katkılar, içermiş olduğu bitki besin elementleri ve hümik asitler nedeniyle bitki gelişimini ve verimliliğini olumlu yönde teşvik ettiği görülmüştür.

Bitkilerde sağlıklı gelişme nedeniyle olası hastalık ve zararlı etkileri baskılanabilmektedir. Bu durum daha az pestisit ve kimyasal kullanımına imkân vermektedir. Soğan üretim alanlarında aşırı gübre kullanımı ve kurak iklim şartları nedeniyle tuzluluk problemlerinin olması bu şekilde bir uygulamanın yapılması tarımsal sürdürülebilirlik, ekonomik fayda ve çevre sağlığı açısından önemlidir.

Çay üretim prosesinde ortaya çıkan atıkların organik gübre katkıları ile kompostlanarak diğer bitki türlerinde kullanılması konuya daha farklı bakış açıları kazandırabilir.

\section{Kaynaklar}

Aktaş, H. Abak, K. Öztürk, L., Çakmak, İ., 2006. The effect of zinc on growth ve shoot concentrations of sodium ve potassium in pepper plants under salinity stress. Turkish Journal of Agriculture ve Forestry, 30: 407412.

Amor del, F.M., Cuadra-Crespo, P., 2012. Plant growthpromoting bacteria as a tool to improve salinity tolerance in sweet pepper. Functional Plant Biology, 39 (1): 82-90.

Apel, K., Hirt, H., 2004. Reactive oxygen species: Metabolism, oxidative stress, ve signal transduction. Annual Review of Plant Biology, 55: 373-399.

Ashraf, M.Y., Awan, A.R., Mahmood, K., 2012. Rehabilitation of saline ecosystems through cultivation of salt tolerant plants. Pakistan Journal of Botany, 44: 6975 .

Bacilioa, M., Morenoa, M., Bashana, Y., 2016. Mitigation of negative effects of progressive soil salinity gradients by application of humic asits ve inoculation with Pseudomonas stutzeri in a salttolerant ve a salt-susceptible pepper. Applied Soil Ecology, 107: 394-404.

Bilkis, A., Islam, M.R., Hafiz, M.H.R., Hasan, M.A., 2016. Effect of $\mathrm{NaCl}$ induced salinity on some physiological ve agronomic traits of wheat. Pakistan Journal of Botany, 48 (2): 455-460.

Chapman, H.D., Pratt, P.F., Parker, F., 1961. Methods Of Analysis For Soils, Plant ve Waters. Üniv. of California, Divission of Agricultural Science Riverside/U.S.A. 60-61: 150-179.

Çağlar, S., 2015. Fındık zurufu kompostu ve çay kompostu karışımlarının kıvırcık marulda (Lactuca sativa L. var. crispa) verim ve kaliteye etkisi. Ordu Üniversitesi Fen Bilimleri Enstitüsü, Yüksek Lisans Tezi, Ordu, 67 s.

Dasgan, H.Y., Aktas, H., Abak, K., Cakmak, I., 2002. Determination of screening techniques to salinity tolerance in tomatoes ve investigation of genotype responses. Plant Science, 163 (4): 695-703.

Fekri, M. Gharanjig, L., Soliemanzadeh, A., 2016. Effects of salinity ve pistachio waste application on growth ve physiological responses of pistachio seedlings. Communications in Soil Science ve Plant Analysis, 47 (1): 112-120.

Hussein, M.M., Faham, S.Y., Alva, A.K., 2014. Role of foliar application of nicotinic asit ve triptofan on onion plants response to salinity stress. Journal of Agricultural Science, 6 (8): 41-51. 
Karal, G., Ugur A., 2014. Lepidium sativum Cultivation in Organic Fertilizer Added Hazelnut Husk Compost. Ekoloji, 23(90): 33-39.

Lima, M.D.B., Büll, L.T., Grassi Filho, H., 2006. Physiological indicies ve nutrient absorption of onion culture under salinity ve hydric stress conditions. Irriga, 11 (3): 356-366.

López-Aguilar, R., Medina-Hernández, D., Ascencio-Valle, F., Troyo-Dieguez, E., Nieto-Garibay, A., ArceMontoya, M., Larrinaga-Mayoral, J.A., Gómez-Veuro, G.A., 2012. Differential responses of Chiltepin (Capsicum annuum var. glabriusculum) ve Poblano (Capsicum annuum var. annuum) hot peppers to salinity at the plantlet stage. African Journal of Biotechnology, 11(11): 2642-2653.

Manan, A., Ayyub, C.M., Pervez, M.A., Ahmad, R., 2016. Methyl jasmonate brings about resistance against salinity stressed tomato plants by altering biochemical ve physiological processes. Pakistan Journal of Agricultural Science, 53(1): 35-41.

Martinez-Beltran, J., Manzur, C., 2005. Overview of salinity problems in the world ve FAO strategies to address the problem. Proceedings of the international salinity forum, Riverside, California, April 2005, 311-313.

Özenç, N., Çalıșkan, N., 2001. Effects of husk compost on hazelnut yield ve quality. Proceedings of the fifth international congress on hazelnut. 27-31 August, 2000, Corvallis, Oregon. 14-18 June, 2004, Tarragona-Reus, Spain.

Özenç, N., Çaycl, G., 2005. The effects of hazelnut husk and other organic materials on hazelnut yield, some soil properties ve quality. Proceedings of the sixth international congress on hazelnut. 14-18 June, 2004, Tarragona-Reus, Spain. , Acta Horticulture 686: 297-307.

Özer, H., 2017. Effects of shading ve organic fertilizers on tomato yield ve quality. Pakistan Journal of Botany, 49(5): 1849-1855.

Pascual, J.A., Garcia, C., Hernveez, T., Ayuso, M., 1997. Changes in the microbial activity of an arid soil amended with organic wastes. Biology ve Fertility of Soil 24: 429-434.

Pitman, M., Läuchli, A., 2002. Global impact of salinity ve agricultural ecosystems. Salinity: Environment-
Plants-Molecules. Kluwer Academic Publishers, Dordrecht, 3-20.

Raza, M.A., Saeed, A., Munir, H., Ziaf, K., Shakeel, A., Saeed, N., Munawar, A., Rehman, F., 2017. Screening of tomato genotypes for salinity tolerance based on early growth attributes ve leaf inorganic osmolytes. Archives of Agronomy ve Soil Science, 63 (4): 501512.

Reddy, N., Crohn, D.M., 2012. Compost Induced Soil Salinity: A New Prediction Method ve Its Effect on Plant Growth. Compost Science \& Utilization, 20 (3): 133-140.

Rengasamy, P., 2006. World salinization with emphasis on Australia. Journal of Experimental Botany, 57: 1017-1023.

Saqib, Z.A., Akhtar, J., Ul-Haq, M.A., Ahmed, I., 2012. Salt induced changes in leaf phenology of wheat plants are regulated by accumulation ve distribution pattern of $\mathrm{Na}+$ ion. Pakistan Journal of Agricultural Science, 49: 141-148.

Scheuerell, S.J., Mahaffee, W.F., 2004. Compost tea as a container medium drench for suppressing seedling damping-off caused by Pythium ultimum. Phytopathology, 94: 1156-1163.

Serrano, R., Gaxicola, R., 1994. Microbial modelsve salt tolerance in plants. Critical Reviews in Plant Sciences, 13: 121-138.

Shannon, M.C., 1997. Adaptation of plants to salinity. Advances in Agronomy, 60: 75-120.

Sikder, M.U., Asadul Haque, M., Jodder, R., Kumar, T., Mondal, D., 2016. Polythene mulch ve irrigation for mitigation of salinity effects on maize (Zea mays L.). The Agriculturists, 14 (2): 01-13.

Suarez, D., 2006. Soil salinity ve farming sustainability related to crop yield ve quality, Meeting abstract: Opportunities ve challenges in Agricultural Water Reuse, Santa Rosa, California, October 29-31, pp. 29-31

Suhail, F.M., Mahdi, I.A., 2013. Test the efficiency of mycorrhizal fungi (Glomus fasciculatum) ve magnetic water to reduce the effect of salinity on plant onion (Allium cepa L.). Bulletin UASMV serie Agriculture, 70 (2): 325-333. 
Tanji, K.K., 1990. Agricultural salinity assessment ve management. ASCE manuals ve reports on engineering practice (USA).
Voss, R.E., Murray, M., Bradford, K., Marberry, K.S., Miller. I., 1999. Onion seed production in California. Division of Agriculture ve Natural Resources, Publication: 8008, ISBN-13: 978-1-60107-188-0. 